\title{
蒸気タービンの翼車不安定流体力の簡易予測手法
}

\author{
矢畑 清志 ${ }^{* 1}$, 山口 和幸 ${ }^{* 1}$, 村田 健一 ${ }^{* 2}$

\section{Simple prediction method of unstable fluid force in turbine blade row}

\section{of steam turbine} \\ Kiyoshi YABATA $^{* 1}$, Kazuyuki YAMAGUCHI ${ }^{* 1}$ and Kenichi MURATA ${ }^{* 2}$ \\ ${ }^{* 1}$ Center for Technology Innovation - Mechanical Engineering, Research \& Development Group, Hitachi, Ltd. \\ 832-2 Horiguchi, Hitachinaka-shi, Ibaraki 312-0034, Japan \\ ${ }^{* 2}$ Steam Turbine Development Strategy Department, Steam Turbine Products Headquarters, MITSUBISHI HITACHI POWER SYSTEMS, Ltd. \\ 3-1-1 Saiwai-cho, Hitachi-shi, Ibaraki 317-0073, Japan
}

Received 25 September 2015

\begin{abstract}
Unstable fluid force may be induced by rotor blade eccentricity in turbo machinery such as steam turbines. To develop a prediction method for unstable fluid force in turbine blade rows, we calculated the fluid force by using computational fluid dynamics (CFD) analysis, and the following conclusions were obtained. In this study, the unstable fluid force acting on the hub of the blade row is 0.8 to 1.2 times as large as that acting on the blades. Therefore, the unstable fluid force acting on the hub is not negligible. We developed a prediction method for unstable fluid force that uses blade tip gap sensitivity to the driving torque on a concentric blade row. The calculation error for the unstable fluid force was less than $11 \%$ compared with the CFD analysis. The maximum pressure location of the circumferential distribution of the perturbation pressure on hub is similar to that on tip seal. And the radial distribution of the perturbation pressure in front of the rotor blade row is uniform. The rotor surface region in front of the rotor blade row is the same as the hub. Therefore, the three dimensional flow is less influence to the unstable fluid force acting on the hub. And the prediction method by Benckert for unstable fluid force on the seal was applied to the hub. The calculation error for the unstable fluid force was less than $16 \%$ compared with the CFD analysis. The total calculation error for the unstable fluid force acting on the blade row was less than $13 \%$ compared with the CFD analysis.
\end{abstract}

Key words: Rotor dynamics, Unstable fluid force, CFD, Steam turbine, Alford's force

\section{1. 緒言}

新興国の経済成長に伴い電力需要が益々旺盛になり, 発電機器市場がグローバルに拡大している.また一方で, 地球環境意識も非常に高まっており，エネルギと環境という二つの課題を同時に解決することが，これまで以上 に強く求められている. 本課題を受けて蒝気タービンでは, より一層の高効率化が求められており, ロータとケ ーシング間のラビリンスシールにおける蒸気漏れ量の低減や翼の多段化による効率の向上などが実施されている。

一方，ロータが回転しながらふれまわることにより負荷依存性のある自励振動が生じる可能性がある。この自 励振動は，励振力に二種類の異なるメカニズムが考えられている。一つはラビリンスシールなどにおける周方向 に非対称な圧力の分布に起因する不安定流体力であり，もう一つは羽根車における周方向に不均一なトルクに起 因する不安定流体力であるAlford力である，これらの不安定流体力は高性能化で増大する傾向にあり，蒸気ター

\footnotetext{
No. 15-00524 [DOI: 110.1299/transjsme.15-00524], J-STAGE Advance Publication date : 26 August, 2016

*1 正員，(株)日立製作所 研究開発グループ 機械イノベーションセンタ（テ312-0034 茨城県ひたちなか市堀口 832-2)

*2 三菱日立パワーシステムズ(株) 蒸気タービン技術本部 タービン開発戦略部（テ317-0073 茨城県日立市幸町 3-1-1）

E-mail of corresponding author : kiyoshi.yabata.vc@hitachi.com
} 
ビンの信頼性確保のためには，これらの流体力の高精度予測が重要である.

ラビリンスシールや翼車まわりに発生する流体力に関しては実験的・理論的な研究報告が多数ある. ラビリン スシールにより発生する流体力については, 以下の研究報告がなされている. Benckertら(Benckert and Wachter, 1980)は種々の形状のラビリンスシールについて流体力を計測し, 不安定流体力とラビリンスシール入口の流入エ ネルギの関係を簡易的な実験式で示している．また，岩壼ら(岩壼他，1983a，1983b，1985，1995)やChilds(Childs， 1993)はNavier-Stokes方程式を出発点として, これを簡略化したバルクフローモデルを構築し, 流体力について実 験と比較をおこなっている. また著者らは, 実験との再現性のよいCFD(Computational fluid dynamics)解析を用いて 種々の形状のラビリンスシールついて不安定流体力の要因を検討している(Nishijima et al., 2013a, 西嶋他, 2013b).

翼車まわりに発生する流体力に関しては，Alfordはロータが回転しながらふれまわるタービンについて，間隙 の狭い位置では翼に受けるトルクが大きく, 間隙の広い位置では翼に受けるトルクが小さいとし, 周方向に不均 一なトルクに起因寸るAlford力について実験式を作成した(Alford, 1965). Motoiらは全周一様な翼端間隙とトルク の関係および局所的な翼端間隙とトルクの関係が等しいと考え, 局所的なトルクから求まる流体力の偏心直角方 向成分を全周積分した結果から不安定流体力を求める予測式を提案している(Motoi et al., 2003). また, Martinez-Sanchezらはスペースシャトルの液体水素ターボポンプのタービン翼車まわりの流体力を模型実験によ って調查しており, Alford力に加え, 周方向に不均一な圧力分布により動翼根元のハブ面が受ける力について言 及している(Martinez-Sanchez et al., 1995). Martinez-Sanchezらの報告を受けて, Songらは周方向に不均一な圧力分 布が静翼と動翼間の流れにより八ブ面に作用していると考えた，そして，八ブ面に作用する不安定流体力の簡易 予測式を作成し，実験による検証を行っている(Song and Martinez-Sanchez, 1997a, 1997b).

従来検討では，動翼根元の八ブ面が受ける不安定流体力について実験と理論式による検討が行われているが, 実機条件における理論式の検証はなされておらず，CFD解析等による現象の詳細分析は行われていない，そこで 本研究では, 翼先端の漏れ流れを防止するチップシールを含んだ, 静翼, 動翼一組のCFD解析モデルを用い, 翼 車まわりの不安定流体力を分析寸るとともに, Benckertらの予測手法を動翼八ブ面に適用した3次元解析が必要な く計算負荷の小さい不安定流体力簡易予測式を提案する.

\section{主な記号}

\begin{tabular}{|c|c|c|}
\hline$f$ & : & 流体力 $[\mathrm{N}]$ \\
\hline$K$ & : & ばね定数 [N/m] \\
\hline$C$ & : & 減衰係数 $[\mathrm{N} \cdot \mathrm{s} / \mathrm{m}]$ \\
\hline$X, Y$ & : & 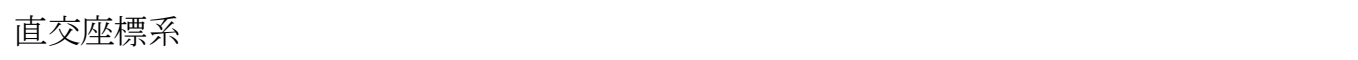 \\
\hline$x, y$ & : & $X お よ ひ ゙ Y$ 方向の変位 $[\mathrm{m}]$ \\
\hline$f_{x,} f_{y}$ & : & $X お よ ひ ゙ Y$ 方向の流体力 $[\mathrm{N}]$ \\
\hline$K_{x x,} K_{y y}$ & : & 偏心方向のロータに作用する偏心量当りの流体力 $[\mathrm{N} / \mathrm{m}]$ \\
\hline$K_{x y}$ & : & ロータのふれまわりを加速する方向に作用する偏心量当りの流体力, 不安定流体力 $[\mathrm{N} / \mathrm{m}]$ \\
\hline$\varepsilon$ & : & 翼車偏心量 $[\mathrm{m}]$ \\
\hline$r$ & : & ロータ半径 $[\mathrm{m}]$ \\
\hline$h$ & : & 動翼高さ [m] \\
\hline$H$ & : & ハブからチップシール静止面までの高さ $[\mathrm{m}]$ \\
\hline$L$ & : & 流路長さ [m] \\
\hline$T$ & : & 動翼のトルク [N·m] \\
\hline$c$ & : & チップシールの間隙 $[\mathrm{m}]$ \\
\hline$c_{u}$ & : & 動翼旋回速度 [m/s] \\
\hline$P_{1,} P_{2}$ & : & 動翼入口および動翼出口の圧力 $[\mathrm{MPa}]$ \\
\hline$E_{Q}{ }^{*}$ & : & 無次元流入エネルギ \\
\hline$K_{Q}^{* * *}$ & : & 無次元不安定流体力 \\
\hline
\end{tabular}




\section{添え字}

$\begin{array}{lll}x, y & : & \text { 方向 } \\ H, L & : & \text { 間隙の大小 }\left(c_{H}>c_{L}\right) \\ \text { in, out } & : & \text { 動翼入口, 動翼出口 } \\ c & : & \text { 動翼の值 } \\ q & : & \text { ハブ上の值 } \\ \text { - } & : & \text { 時間微分 } \\ * & : & \text { 規格化(無次元化)した值 }\end{array}$

\section{2. 解析方法}

\section{$2 \cdot 1$ 不安定流体力の評価}

図 1 に示したロータが軸直角断面における直交座標系 $X, Y$ を取るとき，偏心したロータに作用する流体力は 次式で表せられる(Childs, 1993).

$$
-\left[\begin{array}{l}
f_{x} \\
f_{y}
\end{array}\right]=\left[\begin{array}{cc}
K_{x x} & K_{x y} \\
-K_{x y} & K_{y y}
\end{array}\right]\left[\begin{array}{l}
x \\
y
\end{array}\right]+\left[\begin{array}{cc}
C_{x x} & C_{x y} \\
-C_{x y} & C_{y y}
\end{array}\right]\left[\begin{array}{c}
\dot{x} \\
\dot{y}
\end{array}\right]
$$

ここに $K$ はばね定数， $C$ は減衰係数である $f_{x}, f_{y}$ はそれぞれ $X, Y$ 方向の流体力, $x, y$ はそれぞれ $X, Y$ 方向 の変位であり，は時間微分を示す。

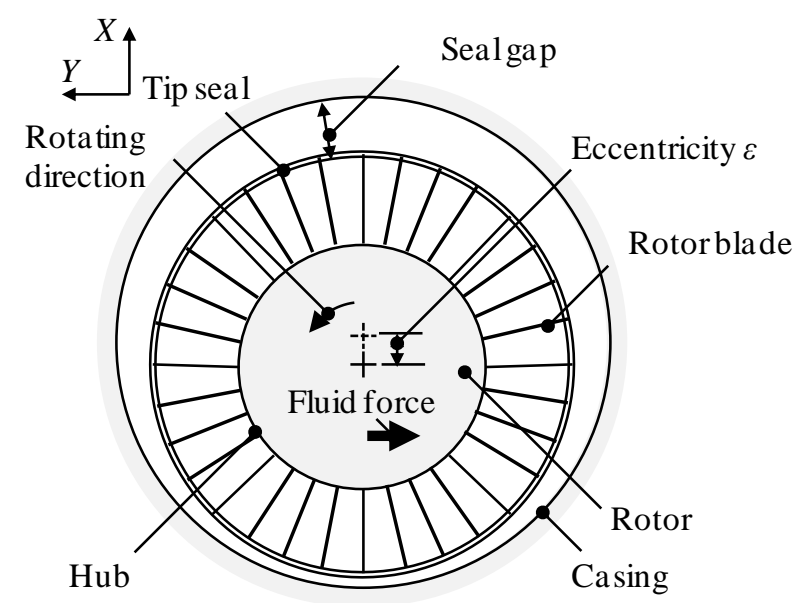

Fig.1 Unstable fluid force in deflected turbine rotor.

式(1)のばね定数の非対角成分 $K_{x y}$ は偏心方向に対してロータの前向きふれまわりを加速する方向に作用する偏 心量当りの流体力である. 以後, この偏心量当りの流体力を不安定流体力と称す. ロータに作用寸る不安定流体 力は, チップシール，動翼，動翼根元の八ブ面に作用する不安定流体力の和で表すことができると考えられる. チップシールの不安定流体力に関しては既報(西嶋他, 2013b)で報告しており, 本報告では翼と八ブ面に作用する 不安定流体力の予測手法について述べる.

\section{$2 \cdot 2$ CFD 解析モデル}

図2に解析モデルの流路断面, 図3にCFD解析モデルとメッシュを示寸. 解析モデルは蒸気タービン1段落分の静 翼, 動翼, チップシールを1組とし, チップシールの静止部をシールギャップの6.25\%偏心させた既報と同一の全 周3次元モデルである(西嶋他，2013b)．本解析では簡便にモデル化するため翼車を偏心させる代わりに静止部を 偏心させた．また，動翼，動翼根元の図中赤破線の八ブ面に作用する不安定流体力は，平均翼端間隙の50\%の偏 
心に対しても線形であることが確認されている(Martinez-Sanchez et al., 1995). 本報告は蒸気タービンの微小な偏 心に対する影響を対象としており，シールギャップの1/10程度の偏心範囲では不安定流体力は線形として取り扱 えると考える. 動翼は根元側をロータハブ面, 先端側をチップシールに接続されている. CFD解析ソフトには汎 用流体解析ソフトである ANSYS ${ }^{\circledR} \mathrm{CFX}{ }^{\circledR}$ (Ver.14.5)を用いた。 支配方程式は, 圧縮性Reynolds Averaged Navier-Stokes 方程式で，定常解析である．また，空間離散化は2次精度風上差分法，乱流モデルにはShear Stress Transport(SST) モデルを使用した．要素数は1500万要素である．流体は実在気体として乾き蒸気である. CFXでは, IAPWS-IF97 に基づく蒸気の状態方程式を扱うことができ, 粘性等の物性はソルバ内部で生成されたテーブルから与えられる. 解析実行時は, 残差の収束を確認するとともに, シールの流体力をモニタして值が一定になることを確認した.

本研究では入口の全圧が高い場合と低い場合の2ケースの解析モデルを作成した.表1にモデルの寸法比を示す.

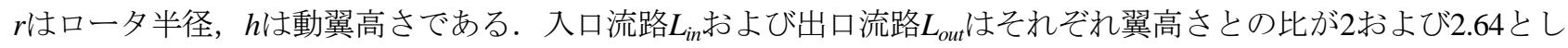
た. 表2に境界条件を示す. 出力をパラメータとし, 入口および出口境界には表 2 示す全圧, 全温, 静圧を一様 に与える. 動翼およびチップシールの動翼側は回転座標系とし, 回転速度は3000 $\min ^{-1}(50 \mathrm{~Hz})$ である. 静翼, 動翼 およびチップシールの間は静止座標と回転座標を接続するFrozen rotorモデルの境界とした(ANSYS ${ }^{\circledR}$, Inc., 2009).

Frozen rotorを用いた場合，静翼と動翼の回転位相が固定された解析となるが，実際には動翼は回転しており，非 定常混合作用が考慮されず，結果が回転位相に若干依存するが，計算負荷を低減するため，この仮定は広く翼列 解析で用いている. 図2(b)にはこのうち静動翼間の境界を示している. 翼枚数はCase1が静翼60枚, 動翼96枚, Case2 が静翼116枚，動翼84枚である.

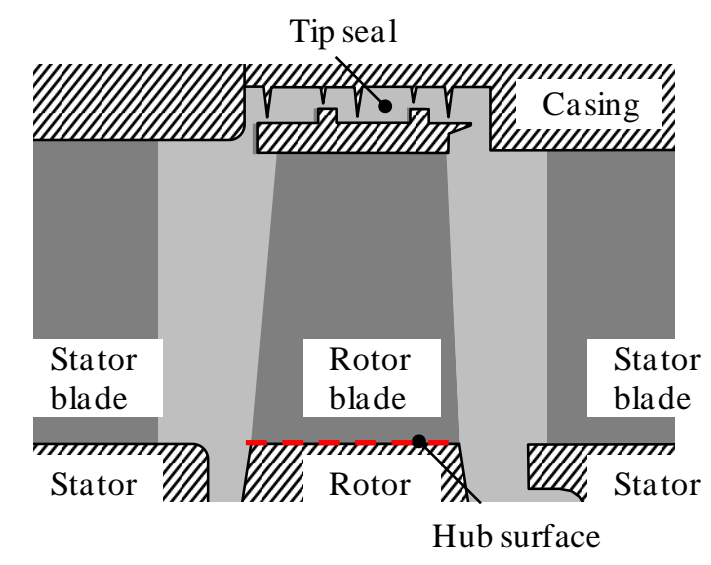

(a) Configuration of geometry of steam turbine stages.

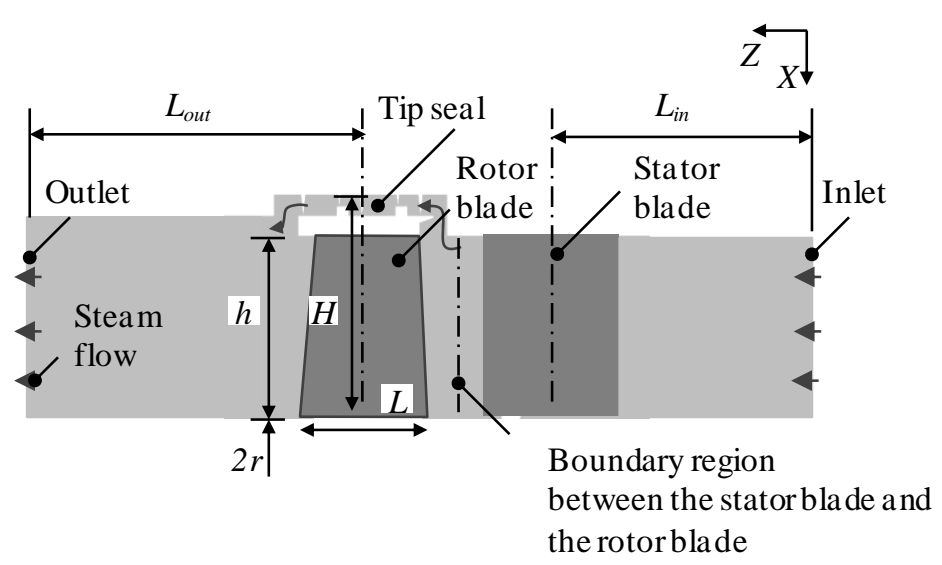

(b) Analysis model.

Fig.2 Analysis model of steam turbine stages.

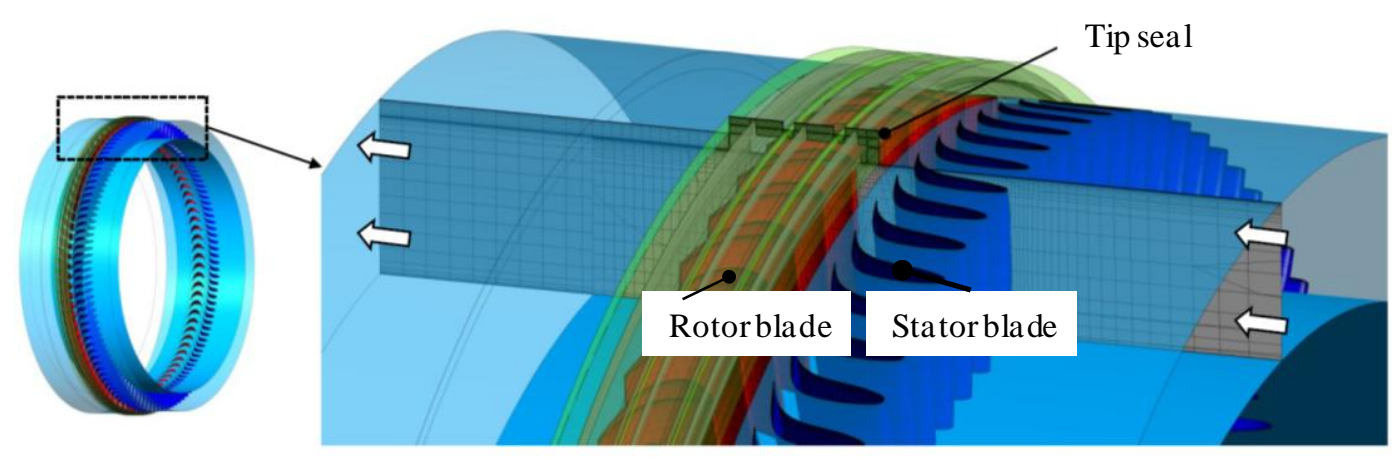

Fig.3 Perspective view of the CFD model with mesh. 
Table 1 Model dimensions.

\begin{tabular}{c|c|c}
\hline \hline Model name & Case 1 & Case 2 \\
\hline $2 r / h$ & 24 & 14 \\
\hline$L_{\text {ir }} / h$ & 2 & 2 \\
\hline$L_{\text {ou }} / h$ & 2.64 & 2.64 \\
\hline
\end{tabular}

Table 2 Boundary conditions.

\begin{tabular}{c|c|c|c|c|c|c}
\hline \hline \multicolumn{2}{c|}{ Model name } & \multicolumn{3}{c|}{ Case 1 } & \multicolumn{2}{c}{ Case 2 } \\
\hline \multirow{2}{*}{ Inlet } & Output (\%) & 80 & 90 & 100 & 90 & 100 \\
\cline { 2 - 7 } & Total pressure (MPa) & 20.3 & 22.8 & 25.3 & 11.0 & 11.2 \\
\cline { 2 - 7 } Outlet & Total temperature (K) & 835 & 835 & 834 & 715 & 713 \\
\hline
\end{tabular}

\section{CFD 解析結果}

\section{$3 \cdot 1$ 翼車まわりに作用する不安定流体力}

図 4 に出力 $100 \%$ における翼およびハブに作用する不安定流体力の計算結果を示す。困の横軸は，式(2)のよう に規格化した. 以降, 不安定流体力 $K_{x y}$ は式(2)のように規格化し, 添え字*を付けて表す.

$$
K_{x y}^{*}=\frac{f}{\varepsilon} \cdot \frac{(2 r+h) h}{T}=K_{x y} \cdot \frac{(2 r+h) h}{T}
$$

ここに $\varepsilon$ は翼車偏心量， $T$ は動翼のトルク，動翼に作用する力は Alford 力である. 対象とした翼車ではハブに 作用する不安定流体力は翼に作用する不安定流体力の $0.8 \sim 1.2$ 倍であり, 動翼のみならずハブに作用する不安定 流体力を予測することが重要である。

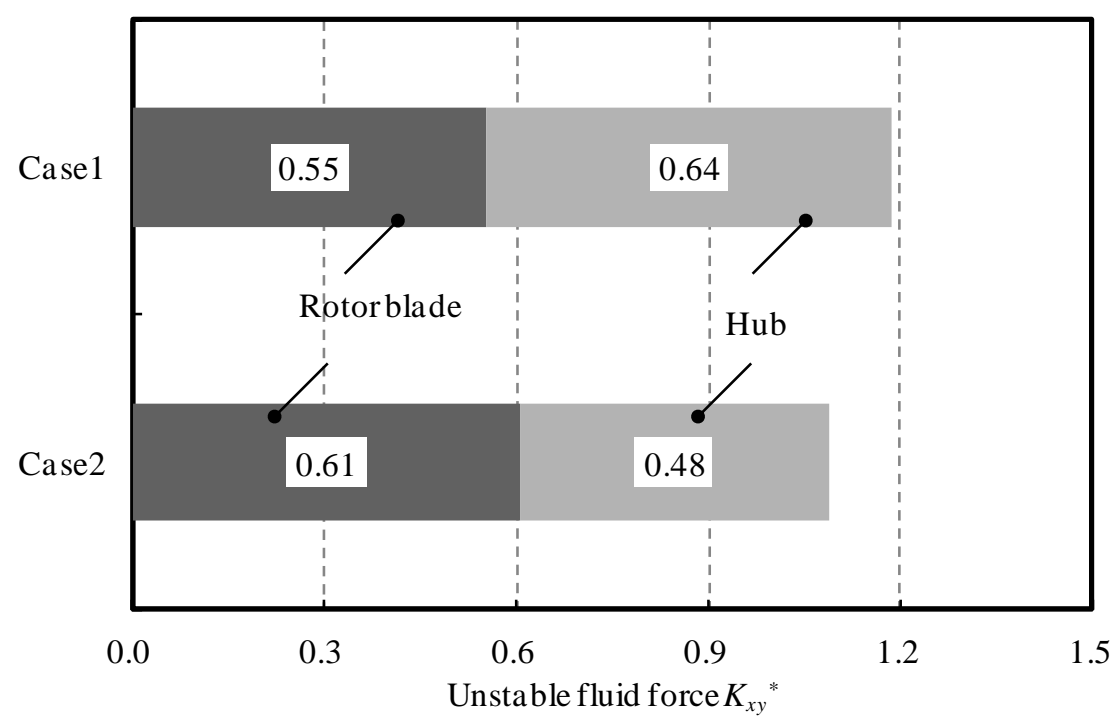

Fig.4 Unstable fluid force on the rotor blade and the hub (Output 100\%).

\section{$3 \cdot 2$ 動翼不安定流体力の周方向分布}

図 5 に Case2 の出力 100\%において各翼のハブに作用する変動圧力の周方向分布を示す. 図の $\theta$ はシールギャ

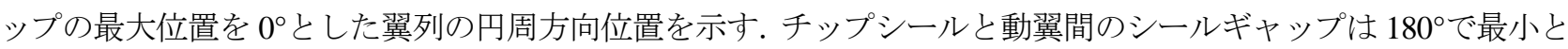


なる. CFD 解析では，静翼，動翼間およびチップシールの間は静止座標と回転座標を Frozen rotor モデルで接続 しており, 静動翼の位相関係が固定される. 翼車の偏心に起因する各翼に作用する変動圧力の周方向分布は静動 翼間の干渉の影響を受ける，そのため，静動翼の位相関係が等しい場所の圧力を平均化することにより静動翼間 の干渉の影響を算出し，これを差し引きすることにより変動圧力を求めた．変動圧力は翼車を加速する方向で全 周積分すると不安定流体力となる. なお, 変動圧力は不安定流体力同様式(3)のように規格化した. 以降, 変動圧 力は規格化し, 添え字*を付けて表す。

$$
P^{*}=P \cdot \frac{(2 r+h) h}{T}
$$

動翼の流入条件の影響を分析するために，図 2(b)に示した静動翼間の境界を周方向の圧力，流速分布を均一化 する Stage モデルとした結果を併記する. Frozen rotor モデルは静動翼間の境界面において圧力, 流速の周方向の 分布を受け渡すのに対し, Stage モデルでは平均化される. Frozen rotor モデルおよび Stage モデルの各翼のハブに 作用する変動圧力の周方向分布は, シールギャップの最小位置から, いずれも $40^{\circ}$ 程度ずれた位置で最大值とな った. Song らは静動翼間の流れにより, 変動圧力の周方向分布の最大圧力位置が決まると報告している. この場 合, 静動翼間の流れをその境界面において変化させればハブに作用する変動圧力の周方向分布も影響を受けるは ずである. しかし，本結果から Stage モデルによって静動翼間の圧力，流速の周方向の分布を平均化しても八ブ に作用寸る変動圧力の周方向分布の圧力最大位置は変化していない.このため, 変動圧力の周方向分布の最大位 置は静動翼間の流れではなく, 動翼部の流れの影響で決定していることが推測される.また, Frozen rotor モデル と比較し, Stage モデルの変動圧力の周方向分布の最大值は小さくなっている. これは, 静翼から動翼先端にかけ て発生している圧力分布が Stage モデルの境界面で均一化され，八ブに作用する圧力分布が均一化されたためと 考えられる.

図 6 に Case2 の出力 100\%おける八ブおよびチップシールのロータ外周面に作用する変動圧力の周方向分布を 示寸. 図 6 は Frozen rotor モデルの計算結果である. 八ブの值は図 5 と等しい值である. 八ブおよびチップシール に作用寸る変動圧力の周方向分布が大きくなる位置は $120^{\circ} \sim 160^{\circ}$ とほぼ同一位置である.

図 7 に動翼直前流路の変動圧力分布を示寸. 周方向の変動圧力分布はシールギャップの最小位置から周方向に 40 程度ずれた位置で最大值をとり, ハブに作用する変動圧力の最大位置と等しい. また, 径方向の変動圧力分布 は, ハブからチップシールにかけてほぼ一様であり, 半径方向流れの影響は小さいと考えられる.

チップシールにおける漏れ流れ方向の圧力損失特性には, シールキャビティ内の渦流れの影響が考えられ, 岩 壼らは, まずシールの漏れ損失を考慮して軸方向の圧力, 流速分布(静特性)を求め, 次に, この静特性を用いて 各キャンバー内の円周方向の圧力分布を求めている，この考えによれば，渦流れはシールの漏れ特性に対しては 大きな影響を与えるが, 円周方向の流れ分布に対寸る渦流れの影響は小さく, 円周方向流れの分布は円周, 軸方 向の2次元流れの影響で生じると考えられる.

翼車において軸流方向の圧力損失特性には, 翼周りの渦流れが影響を与えると考えられる. チップシールと翼 車を比較すると渦の発生メカニズムは異なるが，軸流方向の圧力損失に影響を与える点は共通している．また， 円周方向は, 図7に示寸ようにハブからチップシールにかけて変動圧力分布がほぼ一様であり, 半径方向流れの 影響は小さいため, 渦流れの影響が小さく, 円周方向流れの分布は円周, 軸方向の2次元流れの影響で生じる点も 共通していると考えられる.このため，シールと同様に軸流方向および円周方向流れが支配的であると考えられ る. なお，CFDにおいてはRANS(Reynolds Averaged Navier-Stokes)モデルにおいて渦流れの影響が考慮される. 


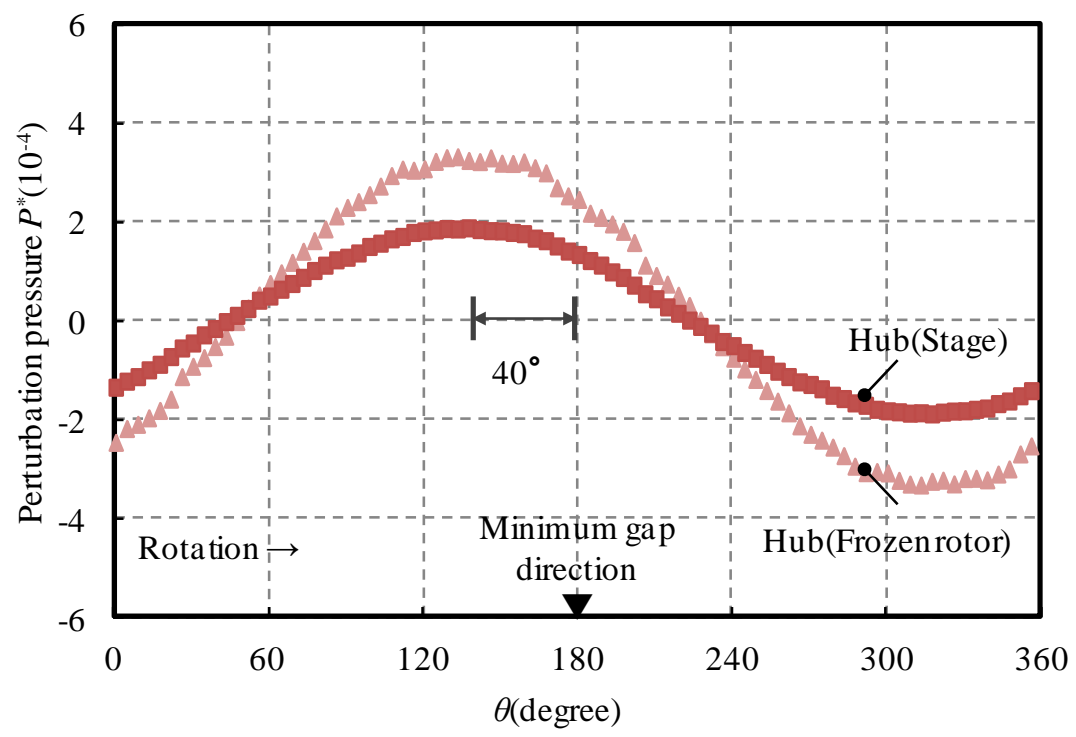

Fig.5 Circumferential distribution of perturbation pressure on the hub. On both models, the location of perturbation pressure become maximum at 40 degrees from minimum seal gap location (Model:Case2,Output:100\%).

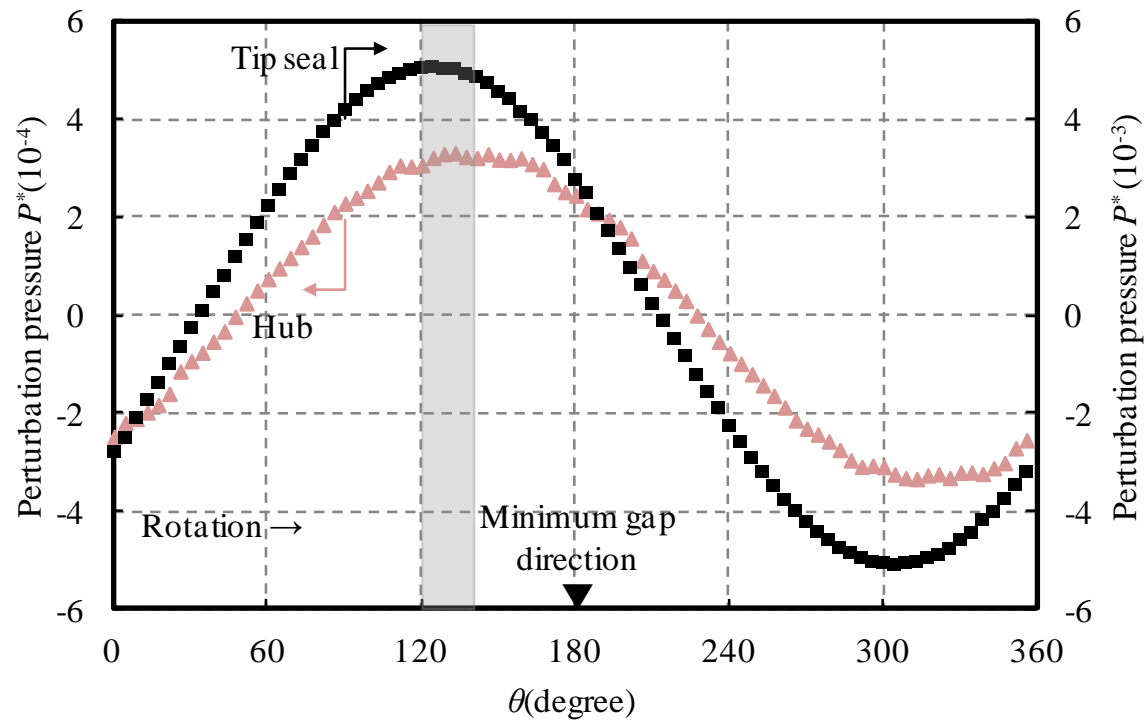

Fig.6 Circumferential distribution of perturbation pressure on the tip seal and the hub. On the hub and tip seal, the location of perturbation pressure becomes maximum between 120 degrees to 160 degrees (Model:Case2,Output:100\%).

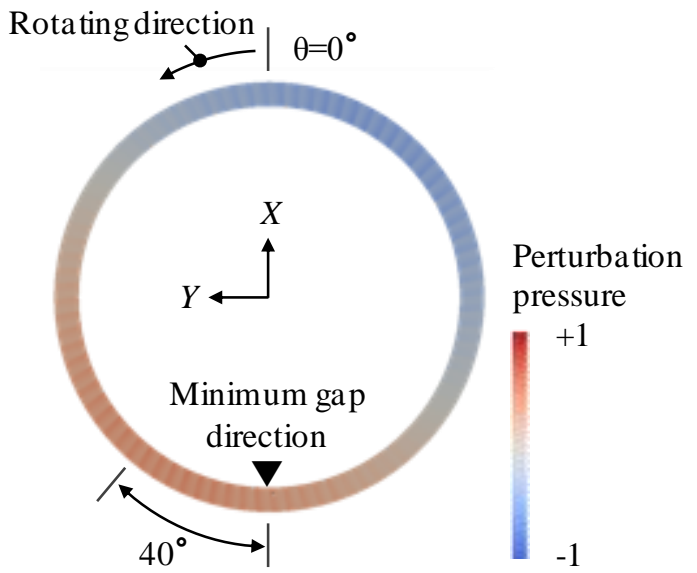

Fig.7 Circumferential distribution of perturbation pressure in front of the rotor blade (Model:Case2,Output:100\%). 


\section{4. 簡易予測手法}

\section{$4 \cdot 1$ 翼に作用する不安定流体力の簡易予測式}

本研究では Motoi らの方法を適用して，翼に作用する不安定流体力を予測する．ロータが回転しながらふれま わるタービンについて，間隙の狭い位置では翼に受けるトルクが大きく，間隙の広い位置では翼に受けるトルク が小さい．このため，翼列は円周方向にトルク分布を生じる．この場合において，翼端間隙の変化によるトルク の変化の割合は全周一様に翼端間隙が変化した場合と等しいと考え, 局所的なトルクから求まる流体力の偏心直 角方向成分を全周積分した結果である式(4)で翼に作用する不安定流体力 $K_{C}$ を予測する.

$$
K_{C}=-\frac{T_{H}-T_{L}}{(2 r+h)\left(c_{H}-c_{L}\right)}
$$

ここに， $c$ はチップシールの間隙， $T$ は動翼のトルク,$r$ はロータ半径， $h$ は動翼高さである．添え字の $H$ およ び $L$ は間隙の大小 $\left(c_{H}>c_{L}\right)$ を示している. チップシールの間隙を変化させた時のトルクは，子午面流れの解析等を 用いることで 3 次元解析より簡便に求めることができる.

式(4)に対して式(2)と同様にチップシール直径と動翼高さの積をトルクで除して規格化を施した不安定流体力 は出力 $100 \%$ で Case1 が 0.58, Case2 が 0.56 となった. 表 3 に動翼に作用する不安定流体力の CFD 解析と式(4) の誤差を示す. 式(4)と CFD 解析の誤差は $11 \%$ 以内でよく一致している.

Table 3 Errors of unstable fluid force acting on the rotor blade (CFD analysis and eq.(4)).

\begin{tabular}{c|c|c|c|c|c}
\hline \hline Model name & \multicolumn{3}{|c|}{ Case 1 } & \multicolumn{2}{c}{ Case 2 } \\
\hline Output (\%) & 80 & 90 & 100 & 90 & 100 \\
\hline Errors as compared with CFD & $0.4 \%$ & $2.5 \%$ & $4.2 \%$ & $-10.3 \%$ & $-7.7 \%$ \\
\hline
\end{tabular}

\section{$4 \cdot 2$ ハブに作用する不安定流体力の簡易予測式}

3.2 節に示したようにチップシールとハブで最大変動圧力の発生位置が近く, 半径方向流れの影響が小さい. 八 ブに作用する不安定流体力の予測にラビリンスシールの予測式である Benckert らの手法を適用することを検討す る. 式(5)にハブに作用する不安定流体力 $K_{Q}$ の予測式を示す.

$$
K_{Q}=\frac{3.6 \cdot \mu \cdot r \cdot L}{H} \sqrt{\frac{\rho_{1}}{2} \cdot c_{u}^{2} \cdot\left(P_{1}-P_{2}\right)}
$$

ここに, 3.6 は係数, $\mu$ は流量係数, $r$ はロータ半径, $L$ は八ブの長さ, $\rho_{1}$ は動翼入口密度, $c_{u}$ は動翼入口旋回 速度， $P_{1}$ は動翼入口圧力， $P_{2}$ は動翼出口圧力である. Benckert らは $H$ をシール高さとしたが，本研究では八ブか らチップシール静止面までの高さとする．流路における流量係数 $\mu$ は式(6)で定義する(深野，1994).

$$
\mu=\frac{q}{A \sqrt{2 \rho_{1}\left(P_{1}-P_{2}\right)}}
$$

ここに, $q$ は流量, $A$ は動翼入口部の流路断面積である. 流量係数 $\mu$ は動翼入口, 出口の圧力差から求めるた め, 翼周りの渦流れの影響で発生する圧力損失の影響が含まれる. 式(6)を式(5)に代入すると式(7)に示寸簡便な式 となる。

$$
K_{Q}=\frac{1.8 r \cdot L \cdot c_{u} \cdot q}{A \cdot H}
$$


式(7) に対して式(2) と同様にチップシール直径と動翼高さの積をトルクで除して規格化を施した不安定流体 力は出力 $100 \%$ で Case1 が 0.57 , Case 2 が 0.42 となった. 表 4 にハブに作用する不安定流体力の CFD 解析と式(7) の誤差を示す. Case1, Case2 ともに CFD 解析との誤差は 16\%以下である.

Table 4 Errors of unstable fluid force acting on the hub (CFD analysis and eq.(7)).

\begin{tabular}{c|c|c|c|c|c}
\hline \hline Model name & \multicolumn{3}{|c|}{ Case 1 } & \multicolumn{2}{c}{ Case 2 } \\
\hline Output (\%) & 80 & 90 & 100 & 90 & 100 \\
\hline Errors as compared with CFD & $-12.2 \%$ & $-11.7 \%$ & $-10.2 \%$ & $-15.6 \%$ & $-13.3 \%$ \\
\hline
\end{tabular}

ここで, 式(5)の係数 3.6 は，ラビリンスシールに対し Benckert らが実験的に求めた無次元不安定流体力と無次 元流入エネルギの関係である式(8)を元にしている.

$$
K_{Q}^{* *}=3.6 \sqrt{E_{Q}^{*}}
$$

ここに，無次元不安定流体力 $K_{Q}^{* * *}$ は，

$$
K_{Q}^{* *}=\frac{H}{\mu \cdot r \cdot L\left(P_{1}-P_{2}\right)} K_{Q}
$$

であり，式(2)に示す規格化ではなくBenckert らの手法を用いている．また，無次元流入エネルギ $E_{Q}{ }^{*}$ は，

$$
E_{Q}^{*}=\frac{\rho_{1}}{2} \cdot c_{u}^{2} \cdot \frac{1}{P_{1}-P_{2}}
$$

である.

図8に無次元不安定流体力と無次元流入エネルギの関係を示す。図にはBenckertの実験結果とCFD解析による Case 1, Case2の計算結果をプロットしている. 図の実線は式(8), 破線はBenckertの実験結果の最大值と最小值を 通過する式(8)の平行線である. シールははく離渦, 翼は翼周り流れにより圧力低下を生じるが, 本質的な円周方 向に生じる流れの分布発生メカニズムは同様と考えられる. そのため, 条件の異なるCase1, Case2はともに最大 值, 最小值の範囲内となり, シールのばらつきの範囲内となった. 以上の結果から, 半径方向流れの影響は小さ く, 対象とした翼車において予測式の精度は良好であることが確認できた。 


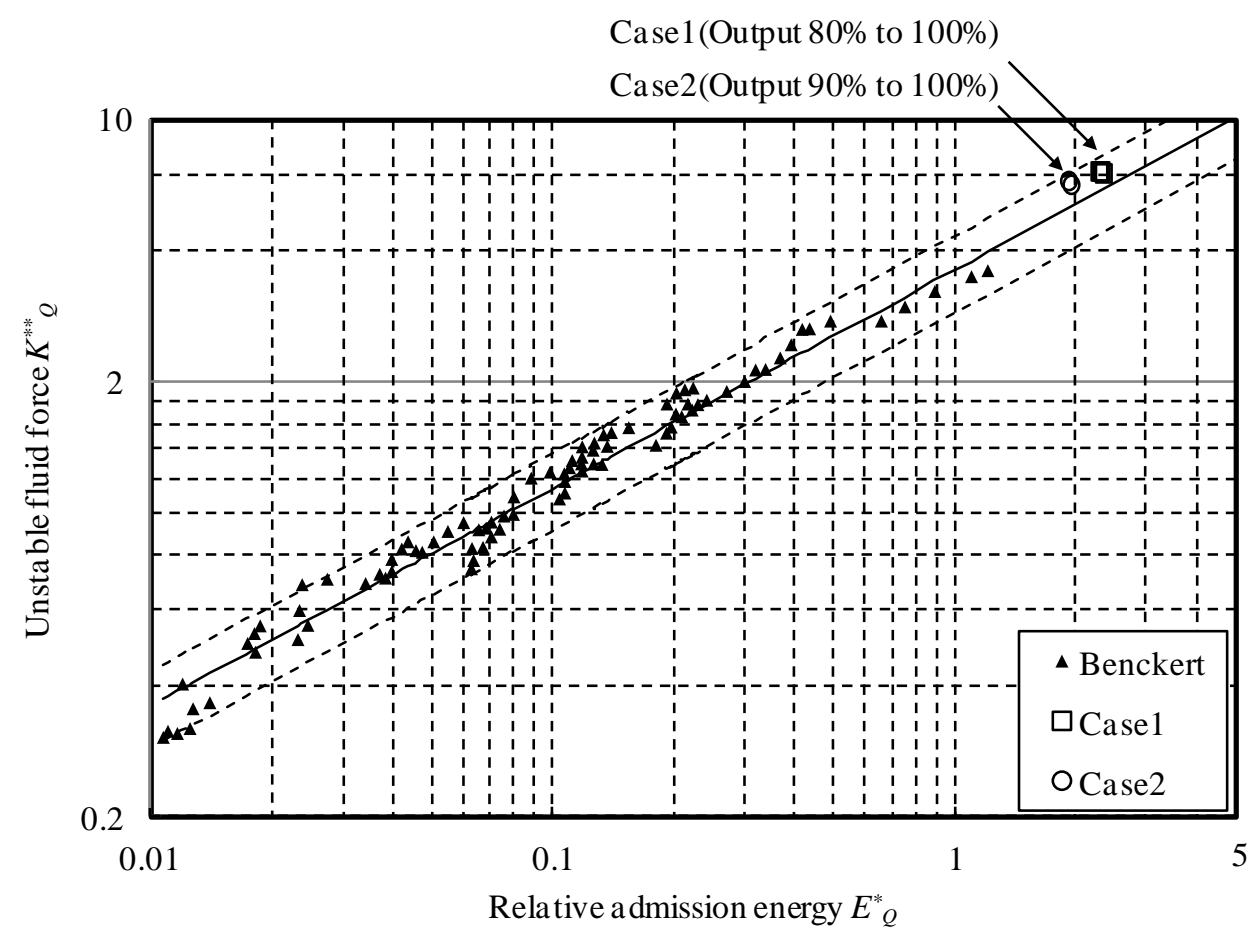

Fig.8 Unstable fluid force and relative admission energy. The dashed parallel lines of eq.(8) on this figure pass through maximum and minimum points of Benckert's results. There are the CFD results $($ Case1,2) between dashed lines.

\section{$4 \cdot 3$ 翼車まわりに作用する不安定流体力と簡易式}

翼車まわりの動翼およびハブに作用する不安定流体力を CFD 解析と簡易式で比較する. 図 9 に出力 $100 \%$ の式 (4)および式(7)を用いた動翼およびハブに作用する不安定流体力, 表 5 に動翼とハブに作用する不安定流体力の誤 差を示寸. 表 5 は動翼および八ブの各誤差の絶対值から最大誤差を算出しており, 図 9 の動翼および八ブに作用 する不安定流体力の合計から求めた誤差とは異なっている．簡易式による翼車周りに作用する不安定流体力の計 算結果と CFD 解析結果の誤差は 13\%以下であり，簡易式により不安定流体力を精度良く予測できることを確認 できた.

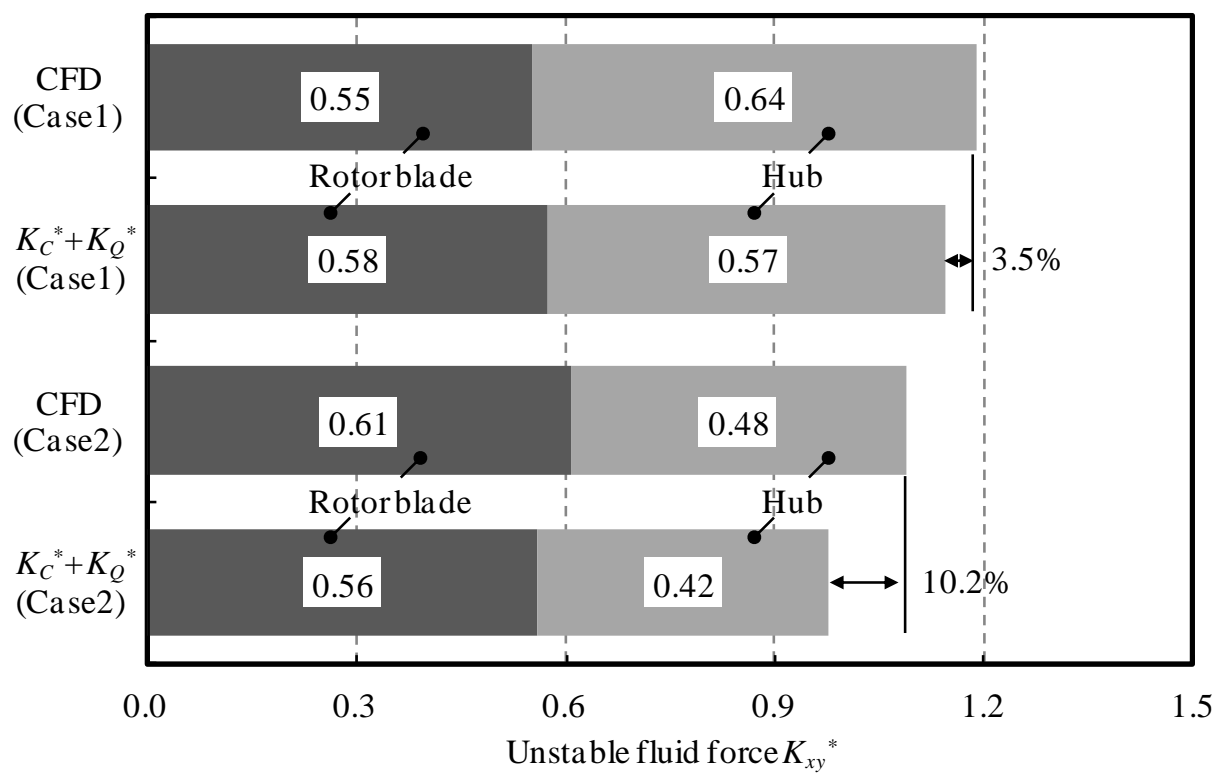

Fig.9 Unstable fluid force on the rotor blade and the hub. Simple equations $\left(K_{C}{ }^{*}+K_{Q}{ }^{*}\right)$ are in good agreement with CFD results on the rotor blade and the hub. 
Table 5 Errors of unstable fluid force acting on the rotor blade and the hub.

\begin{tabular}{c|c|c|c|c|c}
\hline \hline Model name & \multicolumn{3}{|c|}{ Case 1 } & \multicolumn{2}{c}{ Case 2 } \\
\hline Output (\%) & 80 & 90 & 100 & 90 & 100 \\
\hline Errors as compared with CFD & $6.4 \%$ & $8.6 \%$ & $9.3 \%$ & $12.7 \%$ & $10.2 \%$ \\
\hline
\end{tabular}

\section{5. 結 言}

蒸気タービンの翼車まわりの CFD 解析を用いて翼車まわりの不安定流体力を分析するとともに不安定流体力 の簡易予測法を開発し，以下の結論を得た。

(1) CFD 解析の結果, 半径方向流れの影響は小さく, 対象とした翼車では八ブに作用する不安定流体力は翼に 作用する不安定流体力の $0.8 \sim 1.2$ 倍であり，動翼のみならず八ブに作用する不安定流体力を予測すること が重要である.

（2）動翼に発生するトルクに対する翼端間隙の感度を用いた簡易予測式を用いて動翼に作用する不安定流体力 を計算した結果, 定格出力付近(出力 $90 \%$ 以上)の計算誤差は CFD 解析と比較して $11 \%$ 以下である.

(3) チップシールと八ブの変動圧力分布の周方向の最大圧力発生位置は近い. また, 動翼入口の変動圧力の内 周面の分布は八ブの変動圧力分布に等しく, 動翼入口の変動圧力の径方向の分布はほぼ一様であることが 分かった. そのため半径方向流れの影響が小さいことが確認でき, 八ブの不安定流体力の予測に Benckert らのシールの予測式を適用した. その結果, 定格出力付近の計算誤差は CFD 解析結果と比較して $16 \%$ 以下 である.

(4) 翼車まわりの動翼およびハブに作用する不安定流体力の簡易式による定格出力付近の計算結果は CFD 解 析結果と誤差 $13 \%$ 以下で一致し，簡易式の予測精度は良好である.

\section{文献}

Alford, J. S., Protecting Turbomachinery From Self-Excited Rotor Whirl, Transaction of the ASME, Journal of Engineering for Power, Vol.87, No.4 (1965), pp.333-344.

ANSYS, Inc., ANSYS CFX-Solver Modeling Guide (2009).

Benckert, H. and Wachter, J., Flow Induced Spring Coefficients of Labyrinth Seals for Application in Rotor Dynamics, NASA Conf Publ NASA-CP-2133 (1980), pp.189-212.

Childs, D., Turbomachinery Rotordynamics, Phenomena, Modeling,and Analysis, Wiley-Interscience (1993).

深野徹, わかりたい人の流体工学( I ), 裳華房 (1994), pp.157-160.

岩壼卓三, 本岡直人, 川井良次, ラビリンスシールを有する回転軸の不安定振動(第 1 報, 液体モデルによるシー ル内流体力の実験および理論による解析)，日本機械学会論文集 C 編, Vol. 49, No. 441 (1983a), pp.719-726.

岩营卓三, 富田邦洋, 本岡直人, 川井良次, ラビリンスシールを有する回転軸の不安定振動(第 2 報, 近似解法と差

分解法による解析およびパラメータ解析), 日本機械学会論文集 C 編, Vol. 49, No. 443 (1983b), pp.1128-1136. 岩壱卓三, 高原一樹, 川井良次, ラビリンスシールを有する回転軸の不安定振動(第 3 報, シール内でのエネルギ

損失を考慮した理論に基づく流体力), 日本機械学会論文集 C 編, Vol. 51, No. 462 (1985), pp.288-296.

岩壼卓三, 望田秀之, 学賈旭, 直通形ラビリンスシールの動特性に関する研究, 機械力学・計測制御講演論文集,

Vol.B, No.95 (1995), pp.525-528.

Iwatsubo, T. and Iwasaki, Y., Experimental and Theoretical study on swirl braked labyrinth seal, Proceeding of the 6th International Conference on Rotor Dynamics (2002), pp.564-572.

Martinez-Sanchez, M., Jaroux, B., Song, S. J. and Yoo, S., Measurement of Turbine Blade-Tip Rotordynamic Excitation 
Forces, ASME, Vol.117 (1995), pp.384-392.

Motoi, H., Sakazume, N., Saiki, K. and Iwatsubo, T., Sub-Synchronous Whirl In the Le-7a Rocket Engine Fuel Turbo-Pump, ISCORMA-2, Gdańsk, Poland (2003), pp.160-169.

Nishijima, N., Endo, A. and Yamaguchi, K., CFD Investigation on the Rotordynamic Characteristics of Shroud Leakage Flow in High Pressure Steam Turbine, Proceeding of ASME Turbo Expo 2013 (2013a), GT2013-94357.

西嶋規世, 遠藤彰, 山口和幸，タービン動翼先端ラビリンスシールの流体力の数值解析，日本機械学会論文集 $\mathrm{B}$ 編, Vol.79, No.804 (2013b), pp.1546-1560.

Song, S. J. and Martinez-Sanchez, M., Rotordynamic Forces Due to Turbine Tip Leakage : Part I -Blade Scale Effecrs, ASME, Vol.119 (1997a), pp.695-703.

Song, S. J. and Martinez-Sanchez, M., Rotordynamic Forces Due to Turbine Tip Leakage : Part II -Radious Scale Effecrs and Experimental Verification, ASME, Vol.119 (1997b), pp.704-713.

\section{References}

Alford, J. S., Protecting Turbomachinery From Self-Excited Rotor Whirl, Transaction of the ASME, Journal of Engineering for Power, Vol.87, No.4 (1965), pp.333-344.

ANSYS, Inc., ANSYS CFX-Solver Modeling Guide (2009).

Benckert, H. and Wachter, J., Flow Induced Spring Coefficients of Labyrinth Seals for Application in Rotor Dynamics, NASA Conf Publ NASA-CP-2133 (1980), pp.189-212.

Childs, D., Turbomachinery Rotordynamics, Phenomena, Modeling,and Analysis, Wiley-Interscience (1993).

Fukano, T., Introduction to fluid mechanics, Vol.1, Shokabo (1994), pp.157-160 (in Japanese).

Iwatsubo, T., Motooka, N. and Kawai, R., Effect of Flow Induced Force of Labyrinth Seal on Stability of Rotor System : 1st Report, Experimental and Theoretical Analysis of Seal Force by Using Incompressible Fluid, Transactions of the Japan Society of Mechanical Engineers, Series C, Vol. 49, No.441 (1983a), pp.719-726 (in Japanese).

Iwatsubo, T., Tomita, K., Motooka, N. and Kawai, R., Effect of Flow Induced Force of Labyrinth Seal on Stability of Rotor System : Comparison of Approximate Solution and Finite Difference Solution and Parameter Survey, Transactions of the Japan Society of Mechanical Engineers, Series C, Vol.49, No.443 (1983b), pp.1128-1136 (in Japanese).

Iwatsubo, T., Takahara, K. and Kawai, R., The Unstable Vibration of the Rotor with Labyrinth Seals : 3th Report, The Fluid Force Based on the Theory Considering Energy Loss in Labyrinth Seals, Transactions of the Japan Society of Mechanical Engineers, Series C, Vol.51, No.462(1985), pp.288-296 (in Japanese).

Iwatsubo, T., Mochida, H. and Jia, X., Study on dynamic characteristics of labyrinth seals, JSME Dynamics and DesignConference '95 (JSME No.95-8), Vol.B (1995), pp.525-528 (in Japanese).

Iwatsubo, T. and Iwasaki, Y., Experimental and Theoretical study on swirl braked labyrinth seal, Proceeding of the 6th International Conference on Rotor Dynamics (2002), pp.564-572.

Martinez-Sanchez, M., Jaroux, B., Song, S. J. and Yoo, S., Measurement of Turbine Blade-Tip Rotordynamic Excitation Forces, ASME, Vol.117 (1995), pp.384-392.

Motoi, H., Sakazume, N., Saiki, K. and Iwatsubo, T., Sub-Synchronous Whirl In the Le-7a Rocket Engine Fuel Turbo-Pump, ISCORMA-2, Gdańsk, Poland (2003), pp.160-169.

Nishijima, N., Endo, A. and Yamaguchi, K., CFD Investigation on the Rotordynamic Characteristics of Shroud Leakage Flow in High Pressure Steam Turbine , Proceeding of ASME Turbo Expo 2013 (2013a), GT2013-94357.

Nishijima, N., Endo, A. and Yamaguchi, K., Numerical investigation on fluid force acting on rotor blade shroud labyrinth seals, Transactions of the Japan Society of Mechanical Engineers, Series B, Vol.79, No.804 (2013b), pp.1546-1560 (in Japanese).

Song, S. J. and Martinez-Sanchez, M., Rotordynamic Forces Due to Turbine Tip Leakage : Part I -Blade Scale Effecrs, ASME, Vol.119 (1997a), pp.695-703.

Song, S. J. and Martinez-Sanchez, M., Rotordynamic Forces Due to Turbine Tip Leakage : Part II -Radious Scale Effecrs and Experimental Verification, ASME, Vol.119 (1997b), pp.704-713. 